\title{
Comment
}

Cerebrovascular Diseases

Cerebrovasc Dis 2011;31:229

DOI: $\underline{10.1159 / 000322555}$

\section{Treating as Early as Possible with Thrombolysis Is Crucial, but Can We Do Better in the Sub-4.5-Hour Time Window?}

\section{Mark W. Parsons}

Department of Neurology and Hunter Medical Research Institute, John Hunter Hospital, University of Newcastle, Newcastle, N.S.W., Australia

The outcomes from ischaemic stroke patients treated with intravenous thrombolysis in the 3- to 4.5-hour window from the Canadian registry reported in this issue of Cerebrovascular Diseases emphasise that earlier treatment is paramount [1]. Nonetheless, they add to the data that treatment with intravenous tissue plasminogen activator (tPA) in this time window is better than 'standard care' and should be offered to appropriately selected patients [2-4]. It is also notable that the findings from the Canadian registry were identical to that of the larger Safe Implementation of Thrombolysis in Stroke (SITS) international registry, with both the rates of symptomatic intracranial haemorrhage $(\mathrm{ICH})$ and mortality being slightly increased in the 3- to 4.5-hour window compared to patients treated within $3 \mathrm{~h}$ [3]. These remarkably similar outcomes are also a testament to the reliability of data from both registries, which have been criticised in some sectors (without evidence) for not including patients with poor outcomes.

Interestingly, the updated meta-analysis of randomised tPA trials for ischaemic stroke in the 0 - to 6-hour window also showed an increase in mortality with later treatment time, but not for large parenchymal haemorrhage [4]. However, this study did not report symptomatic $\mathrm{ICH}$, which was increased with later treatment in both the Canadian and SITS registries (despite differing definitions). The variability in ICH definition is an ongoing problem; it appears critical to include a clinical deterioration along with a radiologic definition, as a purely imaging-based definition appeared a less sensitive marker of the adverse effect of later treatment with tPA in both registries [1,3]. Nonetheless, the differing definitions of what constitutes clinically meaningful $\mathrm{ICH}$ reflect that the traditional measure of any ICH on imaging with clinical deterioration is not specific enough.

The explanation for the increased mortality seen with later treatment time deserves further investigation. Haemorrhage is not the entire, or even the dominant, explanation, only contributing to around $20 \%$ of deaths $[1,4]$. The higher mortality rate is also not explained by clinical stroke severity, with lower baseline stroke severity seen in both registry studies and the recent meta-analysis in later time windows [2-4]. Could more irreversible tissue damage prior to treatment in the later time window be responsible for worse outcomes? The SITS data suggests so, but the Canadian data does not (in fact there was less early ischaemic change in the later time window). Yet another contradictory finding relating to early ischaemic change on non-contrast CT underlines that this imaging modality has revealed all of its secrets, and we need more precise tissue and vascular imaging to try and understand these recent results. Greater pre-treatment irreversible injury detected with more sensitive imaging (diffusion-weighted MR and perhaps perfusion CT) does predict poorer outcome in later time windows with tPA treatment $[5,6]$. Site of vessel occlusion is clearly important [7]. Other factors remain uncertain. Is clot more difficult to lyse at later time points? What about the role of collateral flow?

The stroke community is spending much (worthwhile) effort on extending the time window for stroke thrombolysis. However, this Canadian study and other recent findings highlight that we must firstly focus on treating more patients earlier; but also, that we still need to improve our success rate (or at least better predict our failures) in the current $<4$.5-hour time window. We must design studies, so long as treatment is not delayed, using advanced brain and vascular imaging to identify the factors that prevent or enhance lytic treatment being effective in individual patients at any treatment time point.

\section{References}

1 Shobha N, Buchan AM, Hill MD; on behalf of Canadian Alteplase for Stroke Effectiveness Study (CASES) Investigators: Thrombolysis at 3-4.5 hours after acute ischemic stroke onset - evidence from the Canadian Alteplase for Stroke Effectiveness Study (CASES) registry. Cerebrovasc Dis 2011;31:223-228.

-2 Hacke W, Kaste M, Bluhmki E, Brozman M, Davalos A, Guidetti D, Larrue V, Lees KR, Medeghri Z, Machnig T, Schneider D, von Kummer $\mathrm{R}$, Wahlgren N, Toni D: Thrombolysis with alteplase 3 to $4.5 \mathrm{~h}$ after acute ischemic stroke. N Engl J Med 2008;359:1317-1329.

- 3 Ahmed N, Wahlgren N, Grond M, Hennerici M, Lees KR, Mikulik R, Parsons M, Roine RO, Toni D, Ringleb P; for the SITS investigators: Implementation and outcome of thrombolysis with alteplase 3-4.5 h after an acute stroke: an updated analysis from SITS-ISTR. Lancet Neurol 2010;9:866-874.

-4 Lees KR, Bluhmki E, von Kummer R, Brott TG, Toni D, Grotta JC, Albers GW, Kaste M, Marler JR, Hamilton SA, Tilley BC, Davis SM, Donnan GA, Hacke W; ECASS, ATLANTIS, NINDS and EPITHET rt-PA Study Group: Time to treatment with intravenous alteplase and outcome in stroke: an updated pooled analysis of ECASS, ATLANTIS, NINDS, and EPITHET trials. Lancet 2010;375:1695-1703.

-5 Parsons MW, Christensen S, McElduff P, Levi CR, Butcher KS, De Silva DA, Ebinger M, Barber PA, Bladin C, Donnan GA, Davis SM; Echoplanar Imaging Thrombolytic Evaluation Trial (EPITHET) Investigators: Pretreatment diffusion- and perfusion-MR lesion volumes have a crucial influence on clinical response to stroke thrombolysis. J Cereb Blood Flow Metab 2010;30:1214-1225.

- 6 Miteff F, Levi CR, Bateman GA, Spratt N, McElduff P, Parsons MW: The independent predictive utility of computed tomography angiographic collateral status in acute ischaemic stroke. Brain 2009;132: 2231-2238

-7 De Silva DA, Brekenfeld C, Ebinger M, Christensen S, Barber PA, Butcher KS, Levi CR, Parsons MW, Bladin CF, Donnan GA, Davis SM; Echoplanar Imaging Thrombolytic Evaluation Trial (EPITHET) Investigators: The benefits of intravenous thrombolysis relate to the site of baseline arterial occlusion in the Echoplanar Imaging Thrombolytic Evaluation Trial (EPITHET). Stroke 2010;41:295-299.

\section{KARGER}

Fax +41613061234 E-Mail karger@karger.ch www.karger.com
() 2010 S. Karger AG, Basel

$1015-9770 / 11 / 0313-0229 \$ 38.00 / 0$

Accessible online at:

www.karger.com/ced
Mark W. Parsons, MD, FRACP

Department of Neurology and Hunter Medical Research Institute

Newcastle, NSW 2310 (Australia)

Tel. +61 24921 3490, Fax +61 249213488

E-Mail Mark.Parsons@hnehealth.nsw.gov.au 